\title{
ENERGY CONVERSION FROM WOODY BIOMASS STUFF: POSSIBLE MANUFACTURE OF BRIQUETTED CHARCOAL FROM SAWMILL-GENERATED SAWDUST
}

\author{
Han Roliadi and Gustan Pari ${ }^{1}$
}

\begin{abstract}
There are three dominant kinds of wood industries in Indonesia which consume huge amount of wood materials as well as generate considerable amount of woody waste stuffs, i.e. sawmills, plywood, and pulp/paper. For the two latest industries, their wastes to great extent have been reutilized in the remanufacturing process, or burnt under controlled condition to supplement their energy needs in the corresponding factories, thereby greatly alleviating environmental negative impacts. However, wastes from sawmills (especially sawdust) still often pose a serious environmental threat, since they as of this occasion are merely dumped on sites, discarded to the stream, or merely burnt, hence inflicting dreadful stream as well as air pollutions. One way to remedy those inconveniences is by converting the sawdust into useful product, i.e. briquetted charcoal, as has been experimentally tried. The charcoal was at first prepared by carbonizing the sawdust wastes containing a mixture of the ones altogether from the sawing of seven particular Indonesia's wood species, and afterwards was shaped into the briquette employing various concentrations of starch binder at two levels (3.0 and $5.0 \%$ ) and also various hydraulic pressures $\left(1.0,2.5\right.$, and $\left.5.0 \mathrm{~kg} / \mathrm{cm}^{2}\right)$. Further, the effect of those variations was examined on the yield and qualities of the resulting briquetted charcoal.

The results revealed that the most satisfactory yield and qualities of the briquetted sawdust charcoal were acquired at $3 \%$ starch binder concentration with $5.0 \mathrm{~kg} / \mathrm{cm}^{2}$ hydraulic pressure. As such, the briquette qualities were as follows: density at $0.60 \mathrm{gram} / \mathrm{cm}^{3}$, tensile strength $15.27 \mathrm{~kg} / \mathrm{cm}^{2}$, moisture content $2.58 \%$, volatile matter $23.35 \%$, ash content $4.10 \%$, fixed carbon $72.55 \%$, and calorific value $5,426 \mathrm{cal} / \mathrm{gram}$. Those qualities revealed that the experimented briquetted sawdust charcoal could be conveniently used as biomass-derived fuel.
\end{abstract}

Keywords: Sawdust waste, briquetted charcoal, starch binder, hydraulic pressure, biomass fuel

\section{INTRODUCTION}

In the early 1900s, charcoal and its altered/modified forms (e.g. moulded/briquetted charcoal) were commonly used as a fuel. In the following period until now, people are still using charcoal and moulded/briquetted products but tend to decline due to a tough competition from other stuffs (e.g. fossil fuels, natural gases, coal, and nuclear/atomic power). However, there are several points to be considered in using such charcoal competitors. At present, fossil oils are not inexhaustible and no longer cheap (Sjostrom, 1981). Further, the use of coal for fuel can release a significant amount of sulfur compounds and thick smoke which are environmentally harmful (Kishimoto, 1969). About nuclear/atomic power, concerns of its safety are still questionable. Meanwhile, natural gases or geothermal have limited uses due to their confined sources (Koch, 1985).

\footnotetext{
${ }^{1}$ Forest Products Research and Development Center, Bogor
} 
For these overall reasons, it is necessary to seek or develop other potential sources for convenient fuel, which can be cost-reasonable, environmentally friendly, and operationally safe. Among the significant sources, attention can be brought to charcoal and its derivatives (e.g. moulded/briquetted charcoal), which result from the charcoaling/carbonization of wood or other ligno-cellulosic stuffs that belong to a biomass or renewable/living matter. Therefore, endeavor in charcoal or briquetted charcoal as fuel can be expectedly satisfy the particular requirements such as its ensured sustainability/renewability, cost-effective processing, friendly environment, and safety.

About the briquetted charcoal, it was introduced to improve its performances for fuel or other uses. The briquetting is often employed when the charcoals are not in a lump form, but rather in small-size particles, such as charcoal particulates, dust, and sawdust charcoal. In the charcoal manufacture, there are four commonly implemented charcoaling/carbonizing batch methods in Indonesia linked to the kiln types, i.e. earth-pit kiln, drum kiln, flat kiln, and semi-continuous kiln. Among the four, the one considered suitable for the small-size woody raw materials (e.g. sawdust) is the drum kiln (Miyakuni and Pari, 2004).

Charcoal production using the drum kiln is relatively cheap and economically convenient, since the kiln material can be of recycled oil drum. In addition, this kiln is versatile and portable, thereby greatly assisting its transfer or move from one location to another. This kiln consists of four main parts, i.e. drum body, drum cover for its upper portion, chimney, and air vents on the vertically circular body (wall) of the drum. Although, the intake amount of small-size woody biomass materials is limited using this kiln (approximately 200-liter capacity), it takes only 2 days for the complete carbonization/ charcoaling, and moreover can be used many times. For these reasons, this kiln conforming to its limited capacity and as described before is suitable for the carbonization of small-size woody biomass materials including the sawdust (Anonymous, 2001 and Pari, et al., 2005).

In the classical manufacture of briquetted charcoal, sawdust charcoal or lump charcoal which has been pulverized into small-size particles is at first mixed/added with binding agent (e.g. tapioca starch, sugar-cane molasses, residual sulphite pulping liquor, etc.), then water is added, and the resulting mixture is transferred to the pressing machine for briquette moulding/shaping (Koch, 1985).

Intended manufacture of briquetted charcoal from sawdust waste in this regard (in Indonesia's case) for fuel is associated with its abundant amount generated from Indonesia's sawmill factories. Production of Indonesia's sawn timber in the last five years (1998/1999 2001/2002) ranged about $415.759-2,707.221 \mathrm{~m}^{3} /$ year (Forestry Statistics of Indonesia, 2003). It was estimated that under active and normal operation of the sawmills, the amount of sawmill wastes could reach $54.24 \%$ of the intake wood logs, of which the sawdust constituted roughly 50\% (Martawijaya and Sutigno, 1990). Concomitant with these figures, it is approximated that the generated sawdust wastes from Indonesia's sawmills can amount to $246.337-1,604.028 \mathrm{~m}^{3}$ /year, quite an abundant quantity.

Judging from the overall previously narrated details, this elaboration looked into the possible endeavor in briquetted charcoal as it has been experimentally manufactured from sawdust that the particular Indonesia's sawmills generate, as part of contributory notion towards broader-scope attempts of "Energy Conversion of Woody Biomass Stuffs" possible manufacture of briquetted charcoal from sawmill-generated sawdust. The manufacture employed varying starch binder concentrations and also varying hydraulic 
Energy conversion from ...... Han Roliadi and Gustan Pari

shaping/briquetting pressures, with the results and other further-related aspects forthcoming.

\section{EXPERIMENTAL METHODS}

\section{A. Materials}

The woody biomass materials for the briquetted-charcoal manufacture were sawdust wastes generated from several Indonesia's sawmills. In this regard, the sawdust wastes were a mixture of the ones alltogether from the sawing of seven particular Indonesia's wood species In addition, tapioca starch was used as a binder during the subsequent moulding/briquetting process.

\section{B. Charcoal Manufacture}

Mixed woody sawdust wastes after reaching their air-dry moisture content and then being cleaned of impurities or unwanted matters (e.g. soil, sand, pebbles, small stones, and other foreign particles) were at first placed inside the drum kiln. Afterwards, the fire-feeding materials or fire starter/inducer which had been put on the inside bottom of the drum were ignited with small amount of kerosene, and the resulting fire was cautiously observed to keep flaming effectively. Further, the upper portion of the drum was closed with the drum cover, and then the chimney installed. During the early stage of thermal degradation (carbonization), only the first 2 - 3 rows of air vents on the circular drum wall from its bottom wall were left open, while the remaining vents above were closed by putting clay or asbestos material.

As the time went on, the charcoaling/carbonization process inside the drum occurred progressively upwards from its lower to upper portion. The carbonization was considered effective when there was a red flame glowing from the burnt sawdust inside the drum, which could be observed through the particular air vent holes. In this situation, such air vents were closed, while those situated above where the flame/glow of the burnt sawdust still had not turned red were kept open. This process proceeded over and over upwards until the red glowing inside the drum eventually reached its top portion, and finally all the air vents were closed. The carbonization was considered perfect/complete when the smoke/gases coming out of the drum chimney became colorless. It took about $6-7$ hours for the complete sawdust carbonization, the content was further let cool for 24 hours, and the resulting sawdust charcoal finally removed for further experimental process.

\section{Moulding/Briquetting Process}

Some amount of the sawdust charcoal was taken, then milled using 80 - 100 mesh crushing machine, and subsequently passed through a 40 -mesh screen. Afterwards, the screened sawdust particles of known moisture content was added with some amount of tapioca starch binder and then water, and subsequently mixed homogenously. Addition of starch binder varied in two concentrations, i.e. 3 and $5 \%$. 
The mixture consisting of sawdust charcoal, water, and starch binder was then shaped into briquetted charcoal using a moulding-equipment. With this equipment, a hydraulic pressure was employed on the mixture in three levels, i.e. $1.0,2.5$, and $5.0 \mathrm{~kg} / \mathrm{cm}^{2}$, for $1-2$ hours, producing a wet cube-formed briquetted sawdust charcoal measuring $3.2-3.3 \mathrm{~cm}^{2}$ in area and $2.8-3.2 \mathrm{~cm}$ in height. The resulting wet briquetted sawdust charcoal was dried in an electric retort at $60^{\circ} \mathrm{C}$ for 24 - 48 hours until reaching constant weight.

\section{Testing the Briquetted Charcoal}

The testing on the briquetted sawdust charcoal was included comprised the yield, density, tensile strength, moisture content, volatile matter, ash content, fixed carbon, and calorific value, which overall were conducted in accordance with the ASTM Standard (1982).

\section{E. Data Analysis}

The data resulting from the briquetted charcoal testing were analyzed using a completely randomized design with factorial pattern. The factors were consecutively starch binder concentrations in two levels (i.e. 3.0 and $5.0 \%$ ), and moulding/briquetting hydraulic pressure in three levels $\left(1.0,2.5\right.$, and $\left.5.0 \mathrm{~kg} / \mathrm{cm}^{2}\right)$. Each of the combined levels between binder concentration and hydraulic pressure was replicated 3 times.

\section{RESULTS AND DISCUSSIONS}

\section{A. Sawdust Charcoal}

Sawdust charcoal as prepared by the charcoaling/carbonization of sawdust wastes afforded the yield of $20.84 \%$ with variability coefficient at $2.62 \%$. That figure was still comparable with the one (i.e. 23.64\%) as experimented by Pari, et al. (2005) who previously carbonized small-size woody biomass particles in the drum kiln.

\section{B. Briquetted Charcoal}

Results of experiment on manufacturing briquetted charcoal from the sawdust charcoal revealed that variation in both starch-binder concentrations and moulding/ briquetting pressures did not significantly affect its yield based on the dry weight of intake sawdust wastes as well as of intake sawdust charcoal (Table 1). Therefore, the yield of briquetted charcoal can be averaged to consecutively $97.2 \%$ and $20.25 \%$ (Table 2). The latter figure suggest the loss of materials during the manufacture of briquetted sawdust charcoal all the way back to the yield of charcoal from sawdust wastes was relatively small, i.e. $0.59 \%$ (20.25\% vs. $20.84 \%$, respectively).

With respect to density and compressive strength, starch-binder concentrations and moulding/briquetting pressures interacted affecting those two properties of briquetted charcoal (Table 1). Further assessment using honestly significant difference (HSD) test hinted that density as well as compressive strength tended to increase with briquetting pressures, 


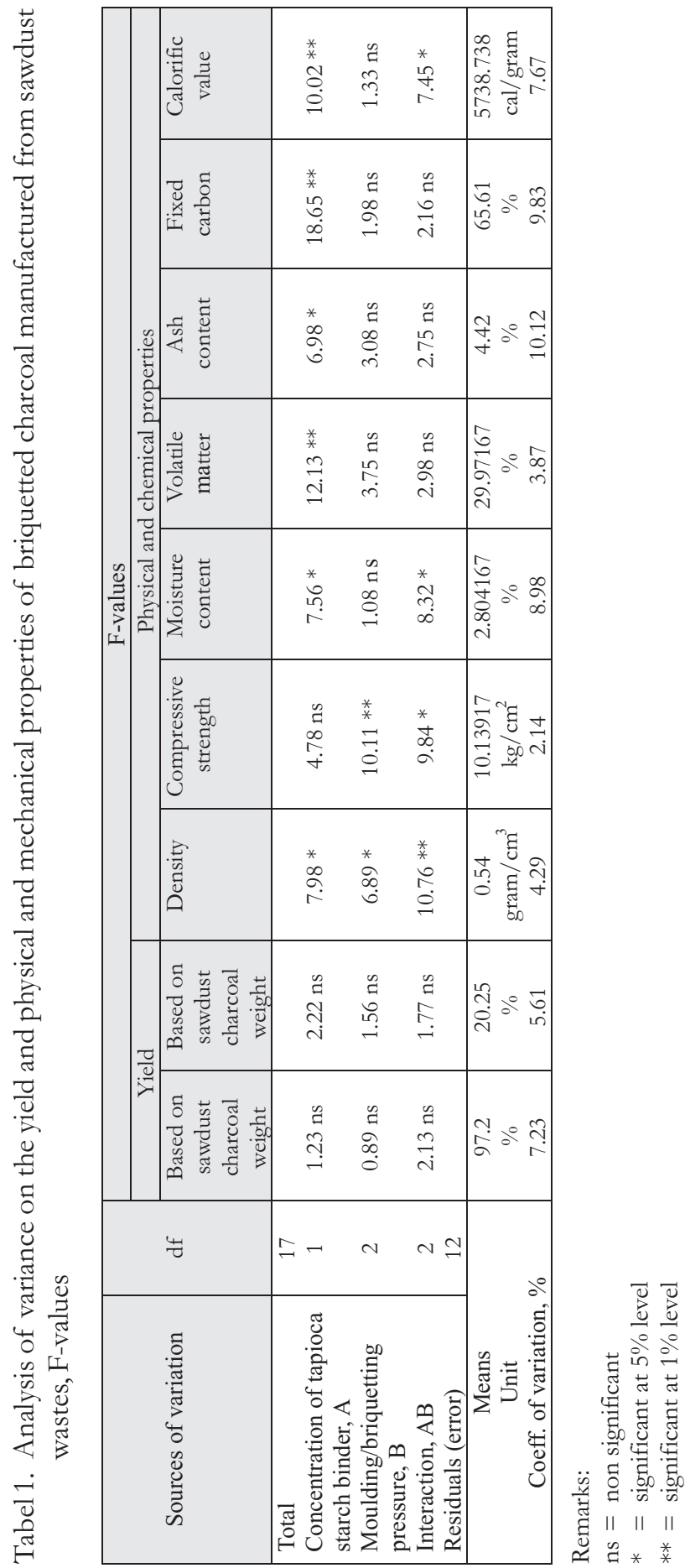



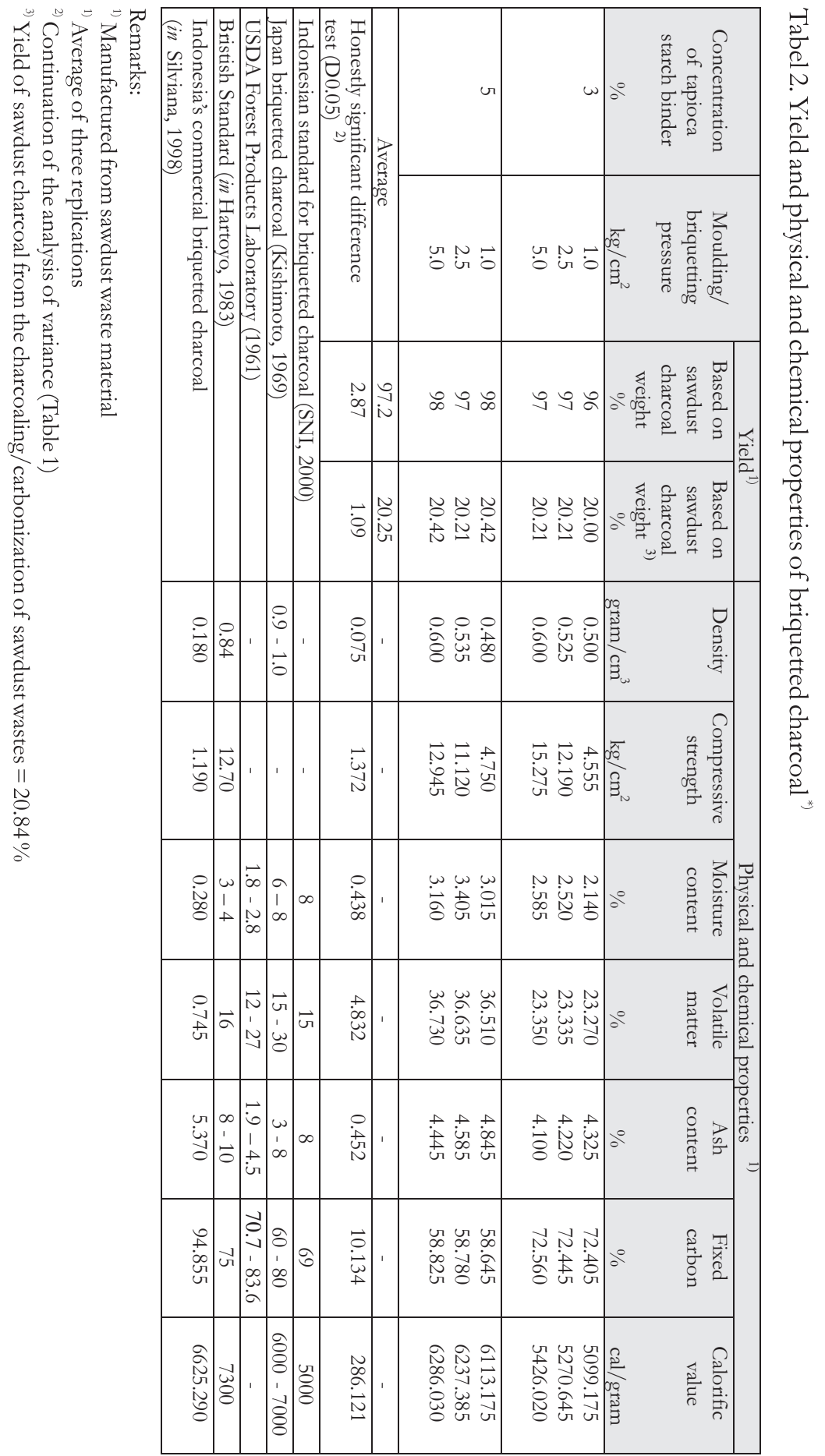
but decrease with binder concentrations (Table 2). This possibly suggests that starch binder is physically weaker than that of sawdust charcoal particles, thereby at greater binder concentration (5\%) allowing more vulnerable structure/space inside the briquetted charcoal during mechanical action (e.g. pressing), and hence lowering the density and compressive strength. On the other hand, greater briquetting pressures could inflict more compacting and packing together of sawdust charcoal particles inside the briquette, thereby increasing the density and compressive strength. The lowest density and compressive strength of briquetted charcoal occurred at $5 \%$ binder concentrations with $1.0 \mathrm{~kg} / \mathrm{cm}^{2}$ briquetting pressure. Meanwhile, the use of $3 \%$ binder concentration with $5.0 \mathrm{~kg} / \mathrm{cm}^{2}$ briquetting pressure inflicted the greatest values of those two properties. Briquetted charcoal with high density and compressive strength is more favored since it can resist/reduce physical damage during the transport or other physical/mechanical handling. Moreover, high-density briquetted charcoal can ensure more effective combusting process.

In the case of moisture content, it was also affected by the interaction between starch binder strength and briquetting pressure (Table 1). Further HSD assessment confirmed that moisture content (MC) of briquetted charcoal increased with binder concentrations as well as briquetting pressures. However, the MC increase with the pressures was more obvious at lower binder concentration (3\%), while at higher concentration (5\%) the MC changes seemed insignificant. The possible phenomena were that starch binder is more water-attracting than sawdust charcoal particles. Further, at higher binder concentration, the inside structure of the briquette charcoal was so packed together thereby allowing no MC changes despite the increase in briquetting pressure. At lower binder concentration, perhaps more capillary structures occured inside the briquetted charcoal with greater moulding pressure rendering more moisture absorption and hence increasing the $\mathrm{MC}$. The lowest $\mathrm{MC}$ of briquetted charcoal was from the use of $3 \%$ binder with $1.0 \mathrm{~kg} / \mathrm{cm}^{2}$ moulding pressure. Concurrently, the use of $5 \%$ binder with $1-2 \mathrm{~kg} / \mathrm{cm}^{2}$ brought about the highest MC. Briquetted charcoal with high MC is unwanted since it can lower its heating/combustion efficiency, and moreover attract particular organisms that can attack/degrade the binder portions.

Volatile matter of the overall briquetted sawdust charcoals seemed that it was not significantly affected by increases in moulding pressure, however it was so and tended to get higher with increased starch binder concentrations (Tables 1 and 2). This suggests that although starch binder contains organic constituents (e.g. carbon and hydrogen), they might be more vulnerable to degradation when the corresponding briquetted charcoal was exposed to high temperature $\left(950^{\circ} \mathrm{C}\right)$ as used for the determination of volatile matters in the charcoal and its derivatives, e.g. briquetted charcoal (More and Johnson, 1967). This situation therefore contributed to highest volatile matters in the briquetted charcoal with $5 \%$ starch binder regardless of varying moulding pressure $\left(1-5 \mathrm{~kg} / \mathrm{cm}^{2}\right)$. On the other hand, lowest volatile content was marked at $3 \%$ starch binder also with $1-5 \mathrm{~kg} / \mathrm{cm}^{2}$ moulding/briquetting pressure. Briquetted charcoal with high volatile content is less favored since it can generate a lot of smoke during the combustion process.

Ash content was not affected by the moulding/briquetting pressure (Table 1). However, it tended to increase with starch binder concentrations, as confirmed through the HSD test (Table 2). Possibly, the tapioca starch used as a binder also contained some amount of inorganic constituents, thereby at greater starch concentration in briquetted charcoal inflicting higher ash content. Highest ash content occurred at $5 \%$ starch binder with 
$1-5 \mathrm{~kg} / \mathrm{cm}^{2}$ moulding/briquetting pressure. Meanwhile, lowest ash content was at $3 \%$ binder also with $1-5 \mathrm{~kg} / \mathrm{cm}^{2}$ pressure. Briquetted charcoal with high ash content during its combustion can cause some problems, since it can induce more formation of slags and clinkers which deposit or stick to the outer metal of the boiler therefore reducing heattransfer efficiency.

Almost similar to ash content, fixed carbon was not affected by moulding/ briquetting pressure (Table 1), but tended to significantly decrease with greater starch binder concentration, i.e. $5 \%$ (Table 2). The plausible explanation is that although starch binder (as organic compound) also contain carbon element, but inside the starch it was not chemically/physically held so strongly as that in the sawdust charcoal hence rendering the carbon more vulnerable/degradable to high temperature $\left(950^{\circ} \mathrm{C}\right)$ as imposed in the determination of fixed carbon content. Lowest fixed carbon in the briquetted sawdust charcoal occurred at $5 \%$ starch binder concentration with $1-5 \mathrm{~kg} / \mathrm{cm}^{2}$ moulding pressure, while the reverse was true at $3 \%$ binder with the corresponding pressure. Briquetted charcoal with high fixed carbon content is more favorable, because it can inflict more effective heating/combusting efficiency.

Calorific value tended to increase with starch binder concentrations as well as with moulding/briquetting pressure (Table 1). However, the role of briquetting pressure was more obvious at lower starch binder $(3 \%)$, while at higher starch $(5 \%)$ there seemed no significant changes in calorific value (Table 2). The possible coherent phenomenon was that at 3\% starch binder, the particles of sawdust charcoal in the briquette became more compact and closed together as the moulding pressure increased thereby inflicting greater heating/combustion efficiency and hence raising the calorific value, although the corresponding fixed carbon content remained practically unchanged (Table 2). In another case, the use of higher starch binder (5\%) brought the briquetted sawdust charcoal with greater calorific value, despite the reverse tendency of the corresponding fixed carbon content (Table 2). Possibly, the use of 5\% starch binder inflicted more packing and closing together of the sawdust charcoal particles as hinted with the more dense briquetted charcoal (Table 2), and again this secured more heating/combustion process hence increasing the calorific value. The lowest calorific value of the briquetted sawdust charcoal signified at $3 \%$ starch binder with $1.0-2.5 \mathrm{~kg} / \mathrm{cm}^{2}$ moulding pressure, while the highest was at $5 \%$ binder with $1-5 \mathrm{~kg} / \mathrm{cm}^{2}$ pressure.

To sum up, compared to Indonesian standard for briquetted charcoal (SNI, 2000), the properties of the experimented briquetted sawdust charcoal could meet the standard (Table 2), except for fixed carbon content (particularly at $5 \%$ starch binder with $1-5 \mathrm{~kg} / \mathrm{cm}^{2}$ moulding/briquetting pressure) and volatile matters. However, referring to those of Japan briquetted charcoal (Kishimoto, 1969), the situation was also similar, except in this experiment for the density and calorific value (particularly the ones with $3 \%$ starch binder and $1-5 \mathrm{~kg} / \mathrm{cm}^{2}$ pressure). Further, in comparison with the requirement of USDA Forest Products Laboratory (1961), the properties of briquetted charcoal could also comply with it, except for volatile matters and fixed carbon content (particularly at 5\% starch binder with $1-5 \mathrm{~kg} / \mathrm{cm}^{2}$ moulding/briquetting pressure). Scrutinizing the British Standard, it turned out that density, compressive strength (particularly the one with $1.0 \mathrm{~kg} / \mathrm{cm}^{2}$ briquetting pressure), volatile matters, a part of fixed carbon, and calorific value of the experimented briquetted sawdust charcoal did not meet the standard (Table 2). At last, referring to the Indonesia's 
commercial briquetted charcoal, the properties of experimented briquetted charcoal still could not comply with its moisture content, volatile matters, fixed carbon, and a part of the calorific value. Expectedly, those drawbacks can be overcome by among others: prolonging carbonization duration (during sawdust charcoal manufacture), and imposing greater briquetting pressure as well as longer drying time (during briquetting process).

\section{CONCLUSION AND SUGGESTION}

The experiment on manufacturing briquetted sawdust charcoal with various starch binder concentrations $(3-5 \%)$ and also with various moulding/briquetting pressure $\left(1-5 \mathrm{~kg} / \mathrm{cm}^{2}\right)$ leads to several summing-ups: Yield of sawdust charcoal carbonized from biomass sawdust waste was $20.84 \%$. Meanwhile, yield of briquetted sawdust charcoal was $97.2 \%$ (based on oven-dry weight of intake sawdust charcoal) or $20.25 \%$ (based on oven-dry weight of sawdust waste), implying that the loss of material from sawdust carbonization until briquetting process was relatively small $(0.59 \%)$. This yield was not affected by starch-binder concentration as well as moulding/briquetting pressure.

Greater starch-binder concentrations brought about the increase in density of briquetted sawdust charcoal, its compressive strength moisture content, volatile matter, ash content, but the decrease in its fixed carbon content and calorific value. Meanwhile, raising briquetting pressure tended also to increase density, compressive strength, and calorific value of briquetted charcoal, but inflicted no significant effect on its volatile matter as well as fixed carbon contents. In general, briquetted charcoal is preferred or more favored with high yield, high density, high compressive strength, high fixed carbon content, and high calorific value, but with low moisture content, low volatile matters, and low ash content.

In comparison with the requirements of Indonesian standard, Japan, USDA Forest Products Laboratory, British Standard, and Indonesia's commercial briquetted charcoal, several properties of the experimented briquetted sawdust charcoal could meet those, with minor exceptions for density, moisture content, volatile matters, and fixed carbon content Expectedly, those drawbacks can be overcome by among others: prolonging carbonization duration (during sawdust charcoal manufacture), and imposing greater briquetting pressure and longer drying time (during briquetting process).

Results of this experiment suggest the favorable prospects of briquetted charcoal manufacture from sawmills-generated sawdust wastes for developing environmentally friendly biomass fuel as alternative or partial substitute for other energy sources (e.g. fossil fuels, coal, and gas/geothermal), which are still questionable about their sustainability/renewability, cost effectiveness, environmental impacts, and operational safety. Such endeavor for Indonesia's case can make use of sawdust wastes abundantly generated by sawmills, which so far still remains unsolved. 


\section{REFERENCES}

Anonymous. 2001. Possible utilization of forest-related woody biomass wastes for wood vinegar, compost and compost charcoal, and mushroom cultivation. Report on the Second Fiscal Year (2000 - 2001)'s Cooperative Project between Research and Development Center for Forest Products Technology (RDCFPT, Bogor Indonesia) and JIFPRO (Tokyo, Japan). Bogor.

American Standard for Testing Material (ASTM). 1982. Standard method of coal and coke. Annual Book of ASTM. Philadelphia, USA.

Forestry Statistics of Indonesia. 2003. Secretary General of Forestry, Ministry of Forestry, Bureau of Planning, Jakarta.

Hartoyo, 1983. The manufacture of briquetted wood charcoal for fuel used in Brunai's households. Forestry of Indonesia (in Indonesian), vol. I (May, 1983), Jakarta, Indonesia.

Kishimoto, S. 1969. Firewood and Charcoal. Wood Chemistry. Tokyo, Japan (limited circulation). $247-256 \mathrm{pp}$.

Koch, P. 1985. Utilization of hardwoods growing on Southern pine sites. October, 1985. USDA (United States Department of Agriculture) Forest Service, Washington, DC 20402, Agricultural Handbook No. 605.

Martawijaya, A. and P. Sutigno. 1990. Increasing the efficiency and productivity of wood processing through the minimization and utilization of wood residues. Seminar on Wood Technology (in Indonesian), January 22 - 1980. Jakarta.

Miyakuni, K. and G. Pari. 2004. Methods of charcoal production to enhance carbon sequestration (Part II). Proceeding of the International Workshop on "Better Utilization of Forest Biomass for Local Community and Environments". Organized by Research and Development Center for Forest Products Technology (RDCFPT, Indonesia) and Japan International Forestry Promotion and Cooperation Center (JIFPRO, Japan), 16 - 17 March 2004. Bogor.

More, W.E. and D.B. Johnson. 1967. Procedures for the chemical analysis of wood and wood products. December 1967. USDA, Forest Services, Forest Products Laboratory.

Pari, G., H. Roliadi, K. Miyakuni and N. Ishibashi. 2005. Trial on some charcoal production methods for the enhancement of carbon sequestration in Indonesia. Proceeding of the Second Workshop on Demonstration Study of Carbon Fixing Forest Management in Indonesia: How to increase the welfare of local people through the sustainable forest management. Organized by Forestry Research and Development Agency (FORDA, Indonesia), and Japan International Cooperation Agency (JICA, Japan), , 11 January 2005. Bogor, Indonesia. 
Silviana, N.A. 1998. Manufacture of briquetted charcoal from woody sawdust wastes, meranti (Shorea sp.) wood, and leave litters. Student Thesis (in Indonesian). Winaya Mukti University, Faculty of Forestry. Bandung, Indonesia.

Sjostrom, E. 1981. Wood Chemistry: Fundamental and Application, Academic Press, Inc. San Francisco - New York - Tokyo - Sydney. 194 -196 pp.

SNI. 2000. Standard requirement for briquetted charcoal in Indonesia. SNI (Indonesian National Standard) No. 01 - 6235 - 2000.

USDA Forest Products Laboratory. 1961. Charcoal production, marketing, and use. USDA, Forest Services, Forest Products Laboratory. Report No. 2213. 